\title{
Impacts of Credit Access on Agricultural Production and Rural Household's Welfares in Northern Mountains of Vietnam
}

\author{
Bui Thi Lam ${ }^{1,2}$, Ho Thi Minh Hop ${ }^{1}$, Philippe Burny ${ }^{1}$, Thomas $\operatorname{Dogot}^{1}$, Tran Huu Cuong ${ }^{2}$, \& Philippe Lebailly ${ }^{1}$ \\ ${ }^{1}$ Economics \& Rural Development, Gembloux Agro-Bio Tech, University of Liège, Gembloux, Belgium \\ ${ }^{2}$ Faculty of Accounting and Business Management, Vietnam National University of Agriculture, Hanoi, Vietnam \\ Correspondence: Bui Thi Lam. Tel: 84-936-309-007. E-mail: btlam@vnua.edu.vn
}

Received: May 29, 2019 Accepted: June 17, $2019 \quad$ Online Published: June 30, 2019

doi:10.5539/ass.v15n7p119 URL: https://doi.org/10.5539/ass.v15n7p119

\begin{abstract}
There is a great consensus on the positive impact of credit access on farmers' incomes and consumption, however, its effect on income inequality among different population segments is still a controversial issue. The paper aims to examine these concerns through using the mixed data collected from the sample of 193 households surveyed (demand-side) and in-depth interviewees with the key credit providers (supply-side) in Lao Cai, the sixth poorest province in Vietnam. At the grass root level, it is evident that better credit access not only significantly positive influences on the effectiveness of agricultural production, but also is the driving force for better structural transition within cultivation versus livestock. Besides this, it enhances both on-farm and off-farm income as well as the well-being of rural households. At the community-impact level, surprisingly, the financial development without agriculture-related supports causes to the negative effect on the distribution of agricultural outcomes and prolongs the inequality in the locality. In addition, an alarm regarding latent social issues has been generating from the preferential credit screen under the community-based lending method. Finally, policy implications are discussed to enhance the effectiveness and outreach of credit in the locality.
\end{abstract}

Keywords: Microcredit, agricultural finance, inequality, household welfare, Northern mountains, Vietnam

\section{Introduction}

Despite the long history and a huge treasure trove of empirical studies, the study of the role of microfinance still has substantial attractiveness. The recent empirical evidence also emphasizes the multi-faceted importance of agricultural investment in developing countries. It is considered a key driver of poverty reduction, food security, improvement of income and the living standards as well as effective risk-coping strategies for farmers (FAO, 2017; 2018 Food and Agriculture Organization; IFC, 2014; Khandker et al., 2016; OI, 2013; Tuan, 2010). According to WorldBank (2008), the only pathway to escape the poverty of smallholder farmers is to enhance agricultural productivity and income, in which credit plays sine qua non for meeting their investment and adopting better technologies. Unfortunately, in fact, farmers in developing countries, like Vietnam, are facing with various endogenous and exogenous barriers to access credit service, that causes to reduce a large of farmers' potential exploited and agricultural productivity (HLPE, 2013). Therefore, the credit scarcity for smallholders must have to end and improve their livelihoods and miserable lives.

In the line of studies of how credit impacts on rural households, the empirical findings show the mixed influence, positively and negatively. The systematically review of Stewart et al. (2012) demonstrates the effects of credit accessibility on households' welfares, but not always, via four aspects comprising: (i) investment in on-farm and/or off-farm activities, consequently, (ii) increase income and expenditure, (iii) enhancement of human capital, and (iv) accumulation of physical assets. The same controversy has also been occurring in Vietnam. The series of following work, like Pham et al. (2019), Bui et al. (2018), Duong et al. (2014), Lensink et al. (2012), proved that better credit access enables to encourage the economic opportunities and enhances the living standard, and so forth. By contrast, Phan et al. (2014) concluded that credit insignificant effects on income, and T. Dufhues (2007), Cuong (2008), Do Xuan et al. (2016) proposed their critical reports that microcredit in Vietnam is designed for the poor and disadvantaged households but its performance serves mainly the non-poor groups. It is also highly questionable whether the remarkably positive achievements of formal credit, especially Viet Nam Bank for Social Policy (VBSP), on poverty reduction and agricultural development, that was shown very well in the official reports (Nguyen et al., 2007; Sauli et al., 2017; Thanh Tam, 2011; World Bank, 2014). Similarly, the 
relationship between financial development and income inequality is still a controversial issue (Beck et al., 2007; Dufhues, 2007; Molini et al., 2008; Mookerjee et al., 2010).

In this paper, Lao Cai is chosen for researching on the above relevant concerns. The province is located in the Northern Midlands and Mountain (NMM), the largest ecological area, concurrently, the poorest region of Vietnam (GSO, 2017). The national investigation (VHLSS 2016) with the sample size of 46,995 households living in 3,133 communes also highlights the relationships among agriculture development, poverty and credit constraints in the NMM region. It reveals that agriculture is the main source of livelihood of $99.8 \%$ of rural communes there and $80.3 \%$ of respondents reported that their lives are significantly improved if agricultural activities are performed favourably. Moreover, among all of obstacles to developing their agricultural production, difficulty in access to credit is reported the highest frequency, $49.0 \%$ (GSO, 2016). Thus, they have to struggle against various consequences regarding the financial shortage. Obviously, it is an urgent need to have a better understanding of the agricultural credit market and possible impacts of these loans in socioeconomic activities of rural households and communities in the locality.

Besides providing an overview of Lao Cai agricultural credit market, the paper examines the role of credit in the locality through two main objectives: (1) the impact of credit status of households on their agricultural production and other welfares (e.g. farm and non-farm income; living expenditure); (2) the relationship between agricultural income inequality and financial development at the district level. To do this, the remainders of the paper are organized as follows. Section 2 explains the methods used for choosing research site, collecting data, and then, analyzing impacts of credit mentioned above. Section 3 presents the results and discussion, comprising an agricultural credit landscape and the impact of different credit sources on different farmer subgroups surveyed. Section 4 concludes the main findings of the paper with some brief policy implications.

\section{Methodology}

\subsection{Research Site and Data Collection}

Lao Cai was selected for representing agricultural credit in mountainous areas of Vietnam because of its economic, political and social importance. It is a border province, close to China; high poverty rate; cultural diversity of ethnic minorities; mountainous terrain with the scarcity of agricultural land and an agriculture-based province. For these reasons, the Vietnamese Government always pays attention to regional development through financing supports over the last three decades. The longstanding questions regarding how are the performance and effectiveness of these subsidies is still fuzzy. This study, therefore, tries to give the clearer answers for these concerns.

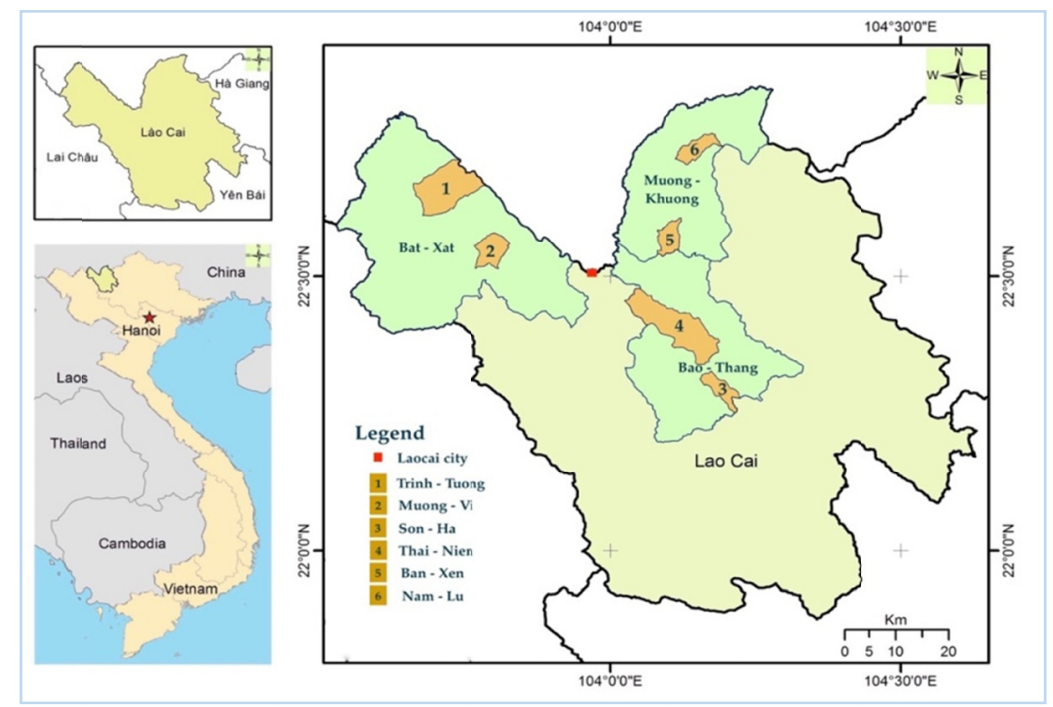

Figure 1. The map of research site (Source: Author's own elaboration)

To obtain a representative sample and reasonable variation, the study was conducted at six villages in six communes of three districts among eight districts of the province (Figure 1). These selected sites were stratified by underlying well-defined criteria as follows:

1. The role of agricultural production in the local economy, that is calculated by its value and share in the total output of agricultural and non-agricultural products/services. 
2. Different competition of financing system at district level measured by a number of formal, semi-formal providers, and their credit volume as well as the average growth rate.

3. Different altitudes (lowland and upland) cause different levels of the agro-ecological zone, productive infrastructure, market access, and demographics;

4. Whether being received financial supports from the central Government. The subsidies are devoted for disadvantaged areas, including poor villages, communes, and districts regulated at 135 (Note 1) and/or 30A (Note 2) programs.

With regards to the household survey, the study selected $50 \%$ of villagers, who are borrowing a loan from VBARD at non-poor villages and $50 \%$ of households taking a loan from VBSP at poor villages. And, $50 \%$ of other people were chosen by the snowball sampling technique to find out the access-constrained credit people during the last two years. The method was introduced by Biernacki et al. (1981) and widespread applied in qualitative sociological research that is hard to identify respondents through the formal way (e.g. drug users, HIV-infected people). Almost surveyed households were stratified in accordance with three levels of wealth classes in the village based on the official poverty baseline issued by MOLISA (2016). The lists of banks' borrowers are taken from the village headmen. In overall, 193 households are selected in this study (Table 1).

Table 1. The explanation of sampling

\begin{tabular}{ccccccc}
\hline Districts & Villages and communes & $\begin{array}{c}\text { Number of } \\
\text { villagers }\end{array}$ & $\begin{array}{c}\text { Banks' } \\
\text { borrowers }\end{array}$ & $\begin{array}{c}\text { Surveyed } \\
\text { Borrowers }\end{array}$ & $\begin{array}{c}\text { Surveyed } \\
\text { Non Borw.s }\end{array}$ & $\begin{array}{c}\text { Total } \\
\text { interviewees }\end{array}$ \\
\hline Bao & & $(1)$ & $(2)$ & $(3)=(2)^{*} 50 \%$ & $(4)=(3)$ & $(5)=(3)+(4)$ \\
Thang & 1. An Dao, Son Ha & 111 & $40^{\mathrm{a}}$ & 20 & 20 & 40 \\
& 2. Do Ngoai, Thai Nien* & 115 & $41^{\mathrm{b}}$ & 20 & 20 & 40 \\
Bat & Sub-total & 226 & 81 & 40 & 40 & 80 \\
Xat & 3. Tan Thanh, Trinh Tuong* & 60 & $22^{\mathrm{a}}$ & 11 & 11 & 22 \\
& 4. Na An, Muong Vi & 69 & $53^{\mathrm{b}}$ & 27 & 26 & 53 \\
Muong & Sub-total & 129 & 75 & 38 & 37 & 75 \\
Khuong & 5. Na Pac Doong, Nam Lu* & 45 & $17^{\mathrm{a}}$ & 9 & 8 & 17 \\
& 6. Na Nin, Ban Xen* & 75 & $21^{\mathrm{b}}$ & 10 & 11 & 21 \\
& Sub-total & 120 & 38 & 19 & 19 & 38 \\
\hline
\end{tabular}

* the communes receive the subsidies from the poverty reduction grants (30A, 135 program)

${ }^{\mathrm{a}},{ }^{\mathrm{b}}$ Focus on the borrowers of Viet Nam Bank for Agriculture and Rural Development and Viet Nam Bank for Social Policy, respectively.

Concerning data collection about financial issues in Vietnam, concisely, it is relatively delicate and not easy to ask directly from both lenders and borrowers. For this reason, the authors combined both formal/direct interview and informal/cross-check data collection in order to achieve a sophisticated analysis of demand-side and supply-side with the best way possible. The study collected both secondary and primary data through our fieldwork conducted from 2016 to 2018.

Firstly, key informant interviews (KI) with 10 local managers related to agricultural development at three administrative levels. Especially, the in-depth interview with the officers working at the State Bank of Vietnam in Lao Cai to synthesize the current policy system, comprising rights and obligations of the particular bank compared to well-intended targets as the central Government's expectation.

Secondly, the in-depth interviews with financial suppliers collect the qualitative data regarding lending performance and the relevant figures in the research topic. At the provincial level, fifteen interviews for all formal and semi-formal financial institutions were conducted but the thoroughness depends on to what extent that provider participates on the agricultural credit market. At the lower level, the author carried out six interviews of the head of credit management of VBARD and VBSP. Besides this, several credit officers and the local authorities also paid attention to exploit their activities in the lending process.

Finally, the well-designed household survey was conducted in order to capture the cross-sectional microdata on (i) general characteristics of respondents; (ii) farming activities; actual and desired investment; (iii) features of credit source obtained and advantages/disadvantages in access; and (iv) the impacts of each credit source on households' agricultural credit and their lives. 


\subsection{Data Analysis}

In order to evaluate the impacts of credit access to households' welfares, in this study, the authors divided the whole sample into three subgroups based on the scale of agricultural production and the status whether or not constraints in credit access. After that, the cross-comparison matrix among them was conducted. The Independent Samples T-Test and the Kruskal-Wallis Test were applied to determine whether there is a statistically significant difference in term of one parametric indicator between two/among more than two unrelated groups, respectively.

The agricultural production in Lao Cai is reflected through indicators used in the value-added analysis named Value Links 2.0 and proposed by GIZ (Springer-Heinze, 2018). Because of the diversity of agricultural production, the study just focuses on agricultural input and output converted consistently into monetary value calculated for the whole 12 months of 2018.

Intermediate Cost (IC) includes the total value of purchasing variable inputs (goods and services) used the agricultural production cycles.

Gross Output (GO) is the total value of main and by-product outputs generated.

Value Added (VA) is the total worth created on agricultural production and calculated the following equations: $\mathbf{V A}=\mathbf{G O}-\mathbf{I C}$

As for the second level of impact estimation, the study examines the relationship between financial development and agricultural income inequality among the rural population surveyed. The Lorenz Curve and the associated Gini Index introduced by Lorenz (1905) and Gini (1912), respectively, are also exploited simultaneously. In essence, these concepts have the same meaning of inequality measurement. The Lorenz curve is a graphical representation, meanwhile, Gini index is expressed as arithmetic. Clearly, this index is between zero and one ( 0 ; 1 ), with the larger values indicating greater inequality and vice versa.

Furthermore, financial development level is estimated based on the causal interaction hypothesized from the structure, conduct, and performance (SCP) mode in the banking sector (Neuberger, 1997). To do this, six indicators were used to evaluate the level of financial development at the district level. They comprise (1) total credit value of the formal sector; (2) its average growth rate in the last five years; (3) the suitability of credit rationing of the commercial bank (VBARD); (4) the suitability of credit allocation of VBSP as Government's mandates; (5) the effectiveness of banks' credit-staffs; (6) the regulation (flexible or inflexible behavior of the leaders of banks) applied for the screening credit process. At each norm, the financing system at the selected district is ranked as its order. As a result, the average score of the formal sector in Bao Thang, Bat Xat and Muong Khuong district takes the value of 3,2 and 1, respectively. It means that Bao Thang has the most effective banking sector, meanwhile Muong Khuong has the lowest level.

\section{Results and Discussion}

\subsection{Overview of the Agricultural Credit Market in Lao Cai}
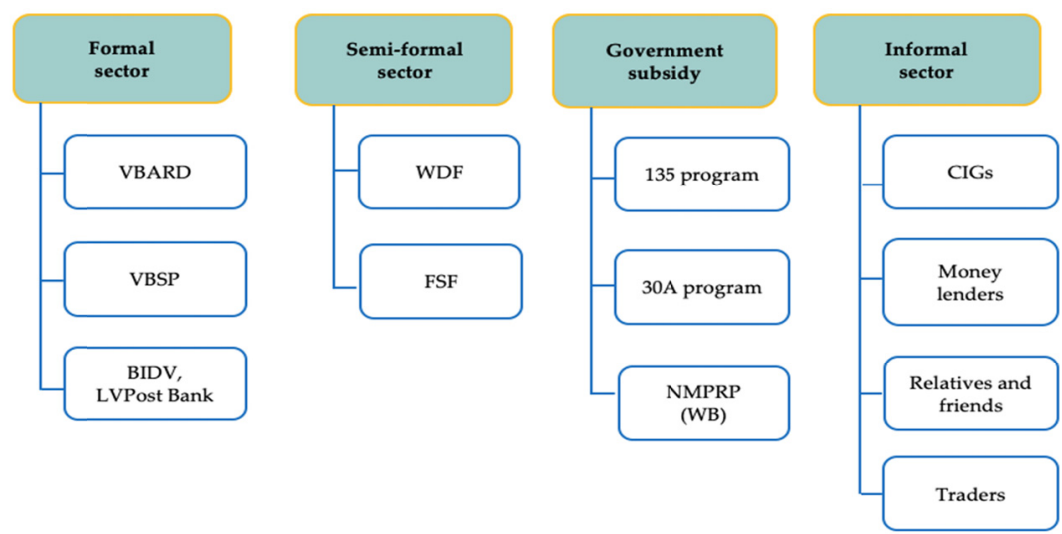

Source: Authors' synthesis, adapted from Sauli et al. (2017), ADB (2010) and Thanh Tam (2011).

Abbreviations: VBARD: Vietnam Bank for Agricultural Development; VBSP: Vietnam Bank for Social Policy; BIDV: Bank for Investment and Development of Viet Nam; LV Post Bank: Lien Viet Post Bank; WDF: Women Development Fund; FSF: Farmer Support Fund; NMPRP: The Northern Mountain Poverty Reduction Project; CIG: Common Interest Group.

Figure 2. Rural financial providers in Lao Cai 
In this section, the study provides an overview of the agricultural credit market in research site with regards to supply, demand and the financial services exchanged in the market. Figure 2 demonstrates the presence of Lao Cai rural financial suppliers, comprising three typical categories (formal, semi-formal and informal) and direct Government's subsidies (i.e. non-reimbursable aid). In spite of the density of formal credit sources, in fact, farmers there are still facing with many difficulties in access these funds for their agricultural production plans. Normally, they, therefore, come to informal credit as the secondary and alternative options. Like previous studies, our study also reiterates the obvious coexistence of informal financial providers, that is well-documented in developing countries in general and Vietnam in particular (T. Dufhues, 2007; Le Thi Minh et al., 2012; Quach et al., 2005; Sauli et al., 2017; Thanh Tam, 2011). Germidis et al. (1991) argued that the reasons for this coexist are weak legal institutions and low levels of income. Furthermore, the financial market in the Northern mountainous region is characterized as the quasi-monopoly and heavy asymmetric information due to principal-agent effects and nepotism. As a result, it causes to not only high transaction costs for both of borrowers and lenders but also creates difficulties in accessibility to (preferential) loans and distorted credit rationing (T. Dufhues, 2007; T. Dufhues et al., 2005; T. B. Dufhues et al., 2002).

The most significant attempt of Vietnamese policymakers in providing credit to farmers is to establish and nurture two state-owned and well-intended banks, VBARD and VBSP, regardless of various criticisms from international/domestic sponsors and researchers (ADB, 2010; T. Dufhues, 2007; Sauli et al., 2017; Thanh Tam, 2011). These banks cooperate together to serve different segments of the rural credit market. VBSP serves low-income borrowers and VBARD provides credit services to higher income customers. Understandably, with huge and multifaceted subsidies, two banks have overwhelming proportions in rural market, tightening the performance of existing financial entities (FSF, WSF) and setting up the high barrier against new financial institutions to entry this market (BIDV, LV Post Bank). Clearly, the rural credit market is operating as the quasi-monopoly, in which VBARD is the largest provider in terms of outstanding loan at $81.24 \%$ (Figure 3.a), meanwhile, VBSP has the biggest share regarding the number of clients at $71.81 \%$ (Figure 3.b) in 2017. Furthermore, a merge consideration here is that these banks have been allocating their loanable fund as the way is not likely appropriate compared to Government's orders. Meanwhile VBARD have to provide credit for agricultural and rural development, but in fact, just only $18.3 \%$ of total credit volume devoted for agricultural production and the remaining proportion, much larger, spent to nonagriculture-related purpose. Similarly, the majority of VBSP-customers are the non-poor (66.8\%). Moreover, in our household survey, a few interviewees are considered the beneficiaries of the poverty reduction, including 135, 30A programs and NMPRP-2 funded by World Bank (Note 3) subsidies. The VHLSS 2016 reported that a mere of $1 \%$ of rural households were benefited from favourable credit belong to poverty reduction project (GSO, 2016). Thus, the credit allocation of banks seems to be a large barrier for the eligible farmers to (preferential) access credit.
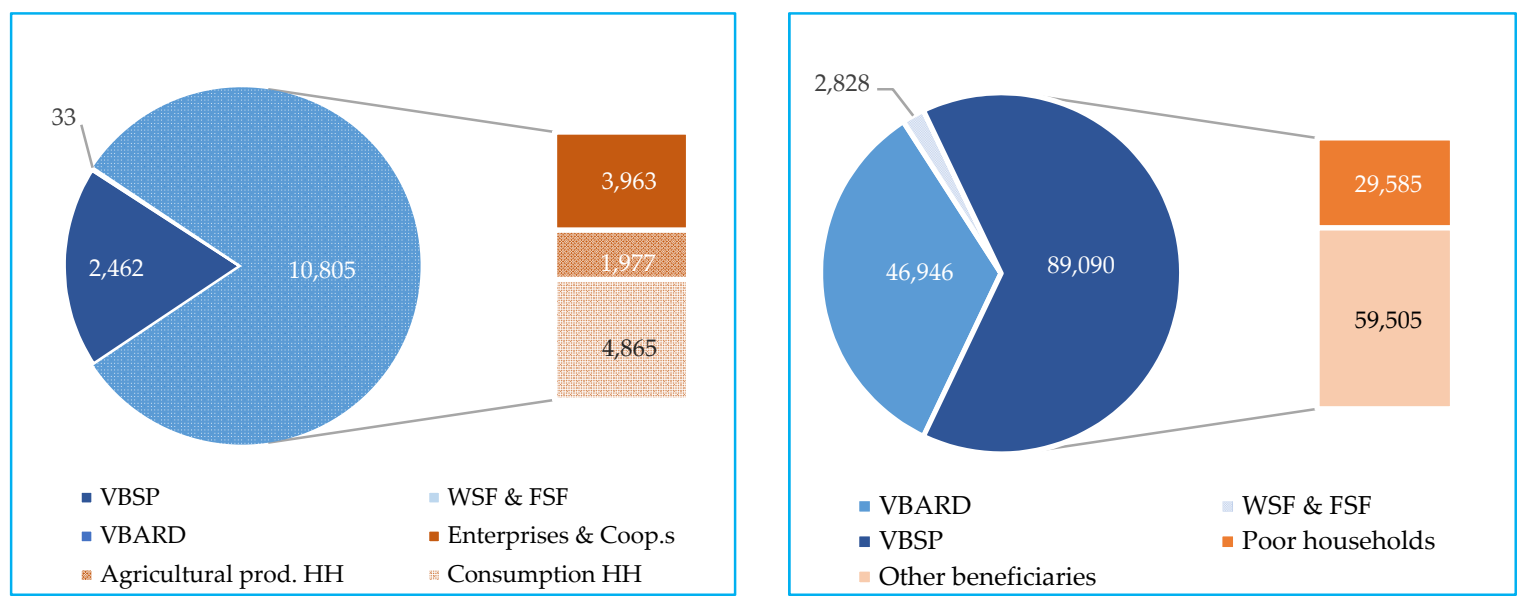

Source: In-depth interviews and annual reports of financial providers surveyed, 2018

Figure 3a. Credit volume of formal and semi-formal providers in Lao Cai, 2017 (Unit: Bil. VND)

Figure 3.b. Households clients accessed formal and semi-formal credit in Lao Cai, 2017 (Unit: households)

Table 2 presents the differentials in terms of loan's obtained by households divided by the different scale of agricultural production, simultaneously, denounces the inequity of disadvantaged households in access to preferential credit, which has been issued for them as the national fiscal burden. 
Table 2. Loan's characteristics obtained by different scale households surveyed

\begin{tabular}{|c|c|c|c|c|c|}
\hline Items & Small-scale HH $(n=50)$ & Medium $\mathrm{HH}(\mathrm{n}=94)$ & Large $\mathrm{HH}(\mathrm{n}=49)$ & Total $(n=193)$ & K.W. Test \\
\hline \multicolumn{6}{|l|}{ VBARD } \\
\hline Loan size (Mil. VND) & 45.83 & 55.58 & 96.66 & 63.49 & $0.02^{* *}$ \\
\hline Interest rate $(\% /$ month $)$ & 0.85 & 0.79 & 0.66 & 0.77 & $0.04^{*}$ \\
\hline Duration (months) & 24.00 & 24.90 & 28.00 & 25.45 & 0.73 \\
\hline \multicolumn{6}{|l|}{$V B S P$} \\
\hline Loan size (Mil. VND) & 31.36 & 32.38 & 33.67 & 32.44 & 0.85 \\
\hline Interest rate $(\% /$ month $)$ & 0.65 & 0.64 & 0.69 & 0.65 & 0.37 \\
\hline Duration (months) & 42.29 & 42.57 & 42.40 & 42.45 & 0.98 \\
\hline \multicolumn{6}{|l|}{ Money lenders } \\
\hline Loan size (Mil. VND) & 10,421 & 11,933 & 13,286 & 11,885 & 0.53 \\
\hline Interest rate $(\% /$ month $)$ & 3.47 & 3.52 & 3.63 & 3.53 & 0.85 \\
\hline Duration (months) & 5.32 & 7.17 & 10.43 & 7.52 & 0.51 \\
\hline \multicolumn{6}{|l|}{ Relative and friends } \\
\hline Loan size (Mil. VND) & 6,867 & 10,609 & 11,250 & 9,802 & 0.21 \\
\hline Interest rate $(\% /$ month $)$ & 0.58 & 0.61 & $\mathrm{~N} / \mathrm{a}$ & - & - \\
\hline Duration (months) & 7.27 & 9.76 & 5.33 & 7.99 & 0.17 \\
\hline
\end{tabular}

${ }^{\mathrm{a}}$ Kruskal-Wallis Test; ${ }^{\mathrm{b}}$ the interest rate charged by relatives and friends was just calculated from the respondents, who had to pay or could convert some non-financial compensations into money they paid.

As currently regulated, all rural farmers equally access to non-collateral loans of VBARD at the maximum of 100 VND million with the subsidized interest rate in disadvantaged areas. In fact, the loan size statistically significant differs among customer groups, that was proportional to their agricultural production and investment scales. It can be seen that the large farmers had a debt, being over twice times as much as the small-scale household's amount. Surprisingly, small farmers suffered from the charge higher than others. The VBARD's staffs reported that small-scale debtors, on average, occur not only the higher transaction cost but also larger repayment risk. Therefore, the higher interest rate charged is considered likely reasonable compensation. Similarly, this behavior is also explained why the poor got a loan charged a higher fee than non-poor and better-off households in rural areas. The problem here is that the Vietnamese Government has granted partly operational cost and subsidized interest rate for VBARD as the compensation, that is proportional to the credit volume provided to disadvantage customers. However, they cannot fully take their eligible advantages. This finding also confirmed by the study of Saito et al. (1981) carried out in the Philippine credit market.

In another hand, traditional finance theory proves the negative impact of the term of loan and positive effect of loan size on lending interest rate under the consideration of price discrimination (Murphy et al., 1977; Varian, 1989). However, in this study, our empirical examination unveils the state that small farmers are suffering from the triple unreasonable disadvantages compared to the basis of market principles. The rationale here is that with a lower loan amount and a shorter term, they should receive lower borrowing interest rates. But the reality is not so. This irrationality was also pointed at the empirical study of Moore et al. (2003) conducted in Barbados, in the Caribbean region. This finding is inconsistent the work of Do Xuan et al. (2016), who stated that formal credit channels are flowing to wealthier people, ethnic majority (Kinh group) and Nguyen et al. (2007), the researchers presented the leakage rates in providing preferential credit was high and rural non-poor clients were the major beneficiaries.

With regards to VBSP, in the policy aspect, this bank provides preferential credit as well-defined programs regulated by Government accordance to with the particular targeting customer. In reality, there are no any significant differentials in terms of loan size, interest rate and duration among observed groups. They look like the same pieces of "welfare cake" divided for all local residents. Furthermore, because of highly subsidized interest and favorable conditions, beneficiaries are able to easily access to non-collateral loans and rarely complain about lending procedures. This point is also confirmed by the study of Sauli et al. (2017) conducted in Kao Bang and Bac Kan, the provinces also belong to the NMM region of Vietnam. It is important to be noted here that the decision making in disbursement without proper assessment of agricultural investment plans or training for loan use cause to high risk of default and the latent financial unsustainability. This has been warned by many domestic researchers and international sponsors (Sauli et al., 2017; Thanh Tam, 2011; WorldBank, 2014), although official reports present good (VBSP, 2018). Thus, there is a large room to examine carefully 
whether to maintain and nurture the cumbersome and ineffective bureaucracy with its loss-making performance.

Concerning the informal sector, as previous predicted, their main customers are normally the lowest segmentation, the group of unsatisfied applicants in the formal sector. Overall, the typical features this credit source are non-mortgage, simple procedure, small size, short-term, and to be used on urgent expenditure, like education fees, health problem, and diseases of crops and/or animals. However, these credit sources widely range of interest rate. Meanwhile, moneylender charged the loans is in very high rate (on average, $3.5 \% / \mathrm{month}$ ) (Note 4), the financial support from relatives and friends have a low rate, even zero. Arguably, using the informal credit often causes the latent socioeconomic shocks for borrowers but they have no better choices. On the other hand, some respondents stated that they always prefer firstly informal loan because of its convenience, quick disbursement and simplicity.

It is time to have a balanced perspective, including positive and negative, about the role of the formal and informal financial sector in developing countries, like Vietnam. Experimental evidence shows that moneylenders have many advantages in their lending method, such as good information on customers, simple procedures, quick disbursement, non-mortgage, flexible interest rate system in accordance with repayment capability and a very high return rate (Dufhues, 2007; Duong et al., 2002; Germidis et al., 1991; Giang, 2004; Madestam, 2014; Quach et al., 2005; Zeller, 1994). Madestam (2014) also add more some interesting observation that informal lenders are able to prevent non-diligent behavior in loan usages, that bank cannot manage well through their local network. The same point of view, Varghese (2004) proposed a lending model namely the "bank-moneylender" linkage. In this, the new method exploits not only the bank's strength in the unlimited loanable fund, but also the private lenders' advantages in screening the local potential customers, credit quality and various good characteristics aforementioned. This model becomes superior to the lending group method of formal sector, in which customers' information is always distorted and incomplete by the local authorities due to nepotism and opportunism and power. Diagne et al. (2000) and Madestam (2014) concluded that formal and informal credit should be designed to become either complements or substitutes rather than to remove totally informal sources. The authors agree with this reasonable suggestion.

\subsection{Impact of Credit Access to Agricultural Production in Lao Cai}

In this section, the central contributions are to estimate the role of each credit source, more focus on formal loan, in agricultural production and households' welfares. With regards to loan's purpose, the most remarkable point here is that households use their loan obtained for various purposes, while formal financial institutions, usually, only disburse a specific purpose (Table 3). In essence, family's finance is fungible between on-farm and off-farm activities, thereby borrowers can be diverted agricultural credit to other income-generating activities, and vice versa (Khandker et al., 2016). Thus, the role of credit is not only in agriculture-related activities but also in other multiple dimensions of rural households.

It can be seen that VBARD-borrowers use the loan for the right purpose, productive and generating-income activities, compared to their application. They also acknowledge the important role and positive impact of VBARD's loan on their farming activities (see Table 4). Pitifully, the coverage of credit provided by VBARD is relatively small.

In respect of VBSP's loan, in spite of its small volume, it was divided into many smaller pieces in accordance with the diversity of household's activities. Moreover, VBSP-clients devoted dominant money for raising castles as an important mean for land preparation and transporting at the harvesting time in rural areas, where agricultural production was taken place on sloppy hills without machinery. With an average loan size about 30 VND million, they are able to buy only one buffalo and able not increase significantly their agricultural investment (i.e. working capital), which can directly improve their productivity and farm income. It is concluded that microcredit provided by VBSP helps poor farmers reduce their miserable work in the fields but its influence on the improvement of income and livelihoods is not clear.

Table 3. Loan purpose of households from main credit sources in the research site

\begin{tabular}{lcccccc}
\hline \multirow{2}{*}{ Sources } & \multicolumn{7}{c}{ Loan was used for .... (\%) } \\
\cline { 2 - 7 } & Cultivation & Livestock & Consumption & Non-farm & Others & Total \\
\hline VBARD & 50.00 & 23.68 & 15.79 & 7.89 & 5.26 & 102.62 \\
VBSP & 36.71 & 63.29 & 48.10 & 3.80 & 5.06 & 156.96 \\
Money lenders & 8.93 & 25.00 & 50.00 & 8.93 & 16.07 & 108.93 \\
Relatives and friends & 7.14 & 21.43 & 90.00 & 9.52 & 4.76 & 132.85 \\
\hline
\end{tabular}

Source: Household survey, 2018. 
In respects of consumption, as argued elsewhere, it is considered a good measure of human well- being (Molini et al., 2008). Normally, it is funded by mostly low non-farm income/wage from their uncertain work in the districts towns or Lao Cai city. Because of its limitation, the vulnerable households also fall in the financial shortage when the harvesting time has not come. In this case, they prefer firstly borrow from informal sectors, in which mainly living expenditure funded from moneylenders and more urgent cases granted by close friends and relatives. An interesting additional observation is that if the poor households have smaller agricultural investment than money availability, e.g. free cash from the banks' debt, this part of money used to improper purpose as their commitment to the bank. The phenomenon takes place if banks apply the lump-sum payment modality (Note 5). Pitifully, nearly $100 \%$ and $82 \%$ of VBSP's and VBARD's debt packages are disbursed through this repayment method, respectively. Table 3 also shows that $50 \%$ of VBSP-borrowers used their loan on consumption although their loan purpose was productive.

Look at Table 4, there are several interesting findings here regarding the role of observed credit source. Compared to the essential role of VBARD in almost agricultural and non-agricultural activities was highlighted, contrary, VBSP has a very faint impact in general and insignificant in the improvement of agricultural activities in particular. Surprisingly, these loans have only significantly improved the living cost and food security. This is explained by two reasons, (i) VBSP has several targeting programs to improve the living standard of rural areas like clean water and sanitary constructions; and (ii) large of borrowers changed their loan purpose from productive to consumptive activities. With regards to the informal sources, it has a strongly positive effect on the cultivated area. In fact, the informal lenders provide the loan size depending on agricultural land of the poor borrowers. This is their most important tactic strategy in cases that the poor cannot pay the debt on time. As a result of the loss of agricultural land, the poor become impoverished and chronic poverty. Clearly, in order to support the poor to escape poverty, it is necessary to have synchronous and comprehensive perspectives, far beyond the simple scope of preferential credit.

Table 4. The result of Pearson Correlations among the loan size of different sources and household's activities

\begin{tabular}{|c|c|c|c|c|}
\hline Terms & VBARD & VBSP & Moneylenders & Relatives \\
\hline 1. $\quad$ Cultivated land & 0.120 & -0.100 & $.363 * *$ & $0.285^{*}$ \\
\hline 2. IC cultivation & $.491 * *$ & -0.057 & -0.154 & -0.115 \\
\hline 3. GO cultivation & $.374 * *$ & 0.052 & -0.200 & -0.142 \\
\hline 4. VA cultivation & 0.124 & 0.122 & -0.208 & -0.138 \\
\hline 5. IC Livestock & $.423 * *$ & -0.029 & 0.199 & $.305^{*}$ \\
\hline 6. GO livestock & $.621 * *$ & 0.019 & 0.188 & 0.119 \\
\hline 7. VA livestock & $.607 * *$ & 0.112 & 0.139 & -0.167 \\
\hline 8. Non-farm income & 0.221 & 0.135 & 0.216 & 0.189 \\
\hline 9. Living cost & $.347 * *$ & $.238^{*}$ & 0.202 & 0.233 \\
\hline
\end{tabular}

Source: Authors' calculation

** and * indicate the significance of Pearson correlation (2-tailed) at the 0.01 level and at the 0.05 level, respectively.

To provide a deeper insight into the contribution of formal credit to economic and non-economic activities, we make the classification the total sample into two categories: constrained and non-constrained households. Figure 4 sketches out the reality of households suffering from difficulties in access to formal credit. Briefly, physical collateral and social capital are the main drawbacks of the poor and smallholder farmer to obtain the satisfied loan from banks. There are two kinds of unsatisfied clients: (i) the group of borrowers received a loan with a lower amount. They are often the medium scale of agricultural production and their capitals (physical, social, human) are evaluated lower than the credit volume in their applications. (ii) the applicants rejected completely, compared to their desire. Sergio et al. (2000) called them the poorest of the poor. Most of them even cannot access to social policy credit because VBSP considers that they are beneficiaries of the poverty reduction programs nationwide $(135,30 \mathrm{~A}$ as mentioned above). In reality, they receive non-reimbursable support, including little agricultural inputs and foods, that just help them to struggle against the hungry in a short time, but, it is not worth to improving their lives in the long term.

Based on the decomposition simultaneously by credit-constrained and agricultural-production-scale categories, the authors make the cross-comparative analyses among subgroups (Table 5). Overall, it makes sense of that there are significant differentials in both of in terms of their investment in cultivation and livestock production and its effectiveness. Credit access effects positively on all agricultural activities of large-scale households, meanwhile this statistically significant impact is only partially presented in the remaining groups. It can be 
explained that these groups of households are limited in access, so they must give priority to investment. Since then, small-scale households tend to improve investment in cultivation with the goal of food security while medium-scale households expect to increase investment in livestock to increase household income. Clearly, to some extent, access to credit has a good influence on the welfare of rural farmers.

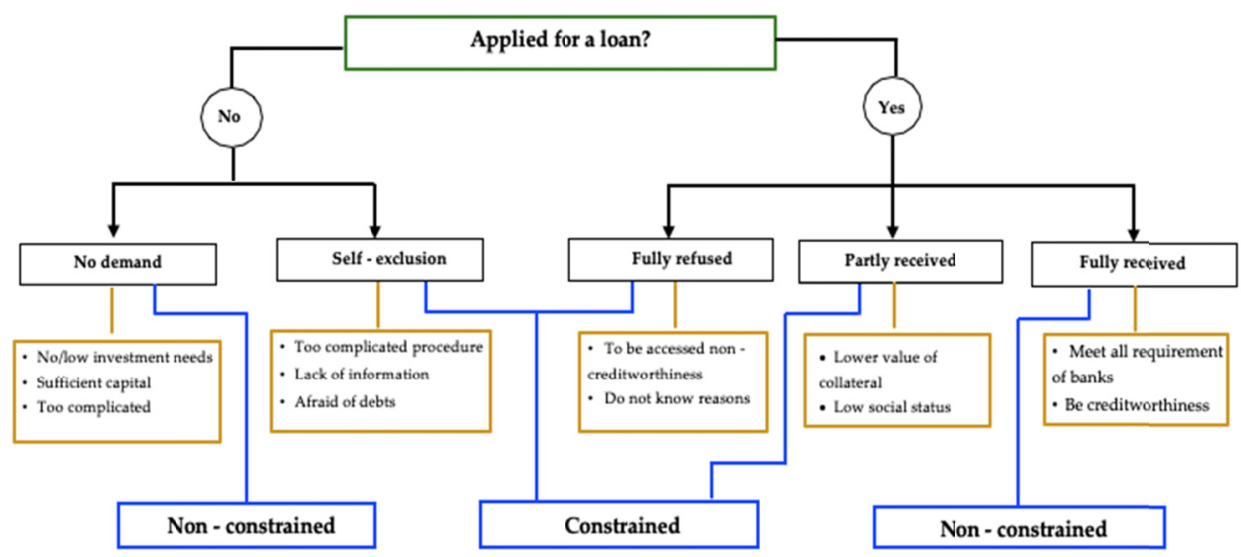

Figure 4. Concept of (non-) credit constrained households developed from Zeller et al. (1996)

Moreover, it is recognized that the structure within agricultural production among subgroups also differ obviously. The larger scale of households is, the higher proportion of their livestock is invested in. More detailed, the share of investment in livestock of the small-scale farmers was about $30 \%$ and dramatically increased at the remaining groups, $72 \%$ (medium) and $85 \%$ (large-scale). In the context of the scarcity of cultivated land, raising animal development plays an essential role in local livelihood and agricultural income diversity. This finding is consistent with the result of Khandker et al. (2016). From this view of point, better credit access is able to open up new economic activities and significantly improve their income.

With respect to the estimation of effectiveness in agricultural production, in principle, the lower IC/GO ratio, the higher efficiency. As can be seen, the ratio is improved apparently both cultivation and livestock of smallholder farmers. This improvement is high meaning in term of food security and nutrient for them, the poor and small peasant farmers. As previously described, the majority of medium groups getting a formal loan tend to invest in raising an animal and their agricultural project has been running well. Compared to access constraint households, the non-constraint farmers obtained higher effectiveness in agricultural production but the differentiation in cultivating is mere and this statistically insignificant.

Table 5. An comparison between households being non-constraints and formal credit access constraints

\begin{tabular}{|c|c|c|c|c|c|c|c|c|c|}
\hline \multirow{2}{*}{ Terms } & \multicolumn{3}{|c|}{ Small-scale $(n=50)$} & \multicolumn{3}{|c|}{ Medium $(\mathrm{n}=94)$} & \multicolumn{3}{|c|}{ Large scale $(n=49)$} \\
\hline & Type A & Type B & T-test & Type A & Type B & T-test & Type A & Type B & T-test \\
\hline \multicolumn{10}{|c|}{ Input and output agriculture production-(mil. VND/household) } \\
\hline 1. IC cultivation & 6.81 & 4.98 & $*$ & 9.32 & 9.61 & $\mathrm{~N} / \mathrm{S}$ & 18.48 & 11.32 & $* *$ \\
\hline 2. GO cultivation & 18.94 & 11.03 & $* *$ & 22.29 & 21.82 & $\mathrm{~N} / \mathrm{S}$ & 40.30 & 25.36 & ** \\
\hline 3. VA cultivation & 12.13 & 6.05 & ${ }^{* *}$ & 12.98 & 12.22 & $\mathrm{~N} / \mathrm{S}$ & 21.82 & 14.05 & * \\
\hline 4. IC Livestock & 1.80 & 3.15 & * & 24.00 & 24.27 & $\mathrm{~N} / \mathrm{S}$ & 109.01 & 61.47 & $* * *$ \\
\hline 5. GO livestock & 4.06 & 5.31 & $\mathrm{~N} / \mathrm{S}$ & 42.85 & 35.65 & * & 155.87 & 90.91 & *** \\
\hline 6. VA livestock & 2.26 & 2.16 & $\mathrm{~N} / \mathrm{S}$ & 18.85 & 11.37 & ${ }^{* *}$ & 50.74 & 29.44 & ** \\
\hline \multicolumn{10}{|l|}{$I C / G O$ ratio } \\
\hline IC/GO cultivation & 0.36 & 0.45 & $* * *$ & 0.42 & 0.44 & $\mathrm{~N} / \mathrm{S}$ & 0.46 & 0.45 & $\mathrm{~N} / \mathrm{S}$ \\
\hline IC/GO livestock & 0.44 & 0.59 & ** & 0.56 & 0.68 & *** & 0.70 & 0.68 & $\mathrm{~N} / \mathrm{S}$ \\
\hline \multicolumn{10}{|c|}{ Non-farm activities (mil. VND/household) } \\
\hline Non-farm income & 14.37 & 5.36 & *** & 12.90 & 9.00 & $*$ & 24.17 & 9.31 & $* * *$ \\
\hline Living cost & 32.26 & 20.05 & ** & 30.04 & 30.30 & $\mathrm{~N} / \mathrm{S}$ & 48.76 & 45.07 & $\mathrm{~N} / \mathrm{S}$ \\
\hline
\end{tabular}

Source: Authors' calculation

Notes: Type A = Non-constraints; Type B = Credit access constraints

${ }^{* * *},{ }^{* *}$, and ${ }^{*}$ indicates the statistically significance at $1 \%, 5 \%$ and $10 \%$ in the T-test, respectively. 
On the other hand, the cross-comparison among subgroups reveals that the larger scale of agricultural investment, the lower performance obtained (a considerable increase of IC/GO). This situation seems to contradict the economies of scale in microeconomics theories. It is explained that smaller households with low investment level but they are able to exploit natural inputs from agricultural land, leading to higher effectiveness. In the case, they succeed in accessing credit and enhance their investment, the efficiency of agricultural production will be significantly increased. Meanwhile, many larger households do not pay attention to agricultural production and proper farming practices because of the competition related to time used for agricultural and non-agricultural activities.

The interviews with local farmers indicate that formal credit helps them buy transportation mean (motorbike), and hence, enhance market accessibility, that bring many socioeconomic benefits for them as below. The most important aspect is non-farm income from self-employment work (i.e. street vendors, builders, hired labourers) in district towns and/or Lao Cai city. Followed by, they can sell/buy directly agricultural input and output at the local market with better price and quality. The last one was mentioned that their knowledge and skills, may or may not, relate to agriculture production, enhanced through the tribe working together. It is concluded that the formal credit creates, short term or long term and direct or indirect, opportunities for bank-borrowers to market accessibility, comprising labor, agricultural input/output. Thus, both of non-farm income and living expenditure was significantly improved, that is also an important strategy of crop risk and smoothing consumption (Note 6). These findings confirm the empirical studies in Vietnam about the significantly positive role of credit access in improving rural household's welfares, agriculture and other earned sources, food security, smoothing consumption as well as contributing to the poverty alleviation (Cuong, 2008; Lensink et al., 2012; Pham et al., 2019; Phan et al., 2014).

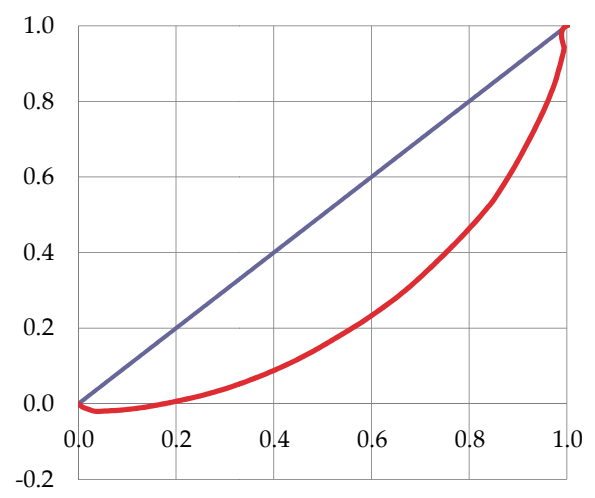

Lao Cai province $(\mathrm{G}=0.5242)$

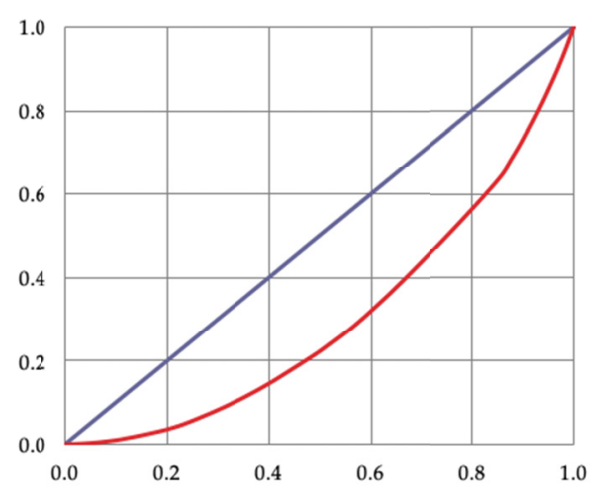

Bat Xat district $(\mathrm{G}=0.3963)$

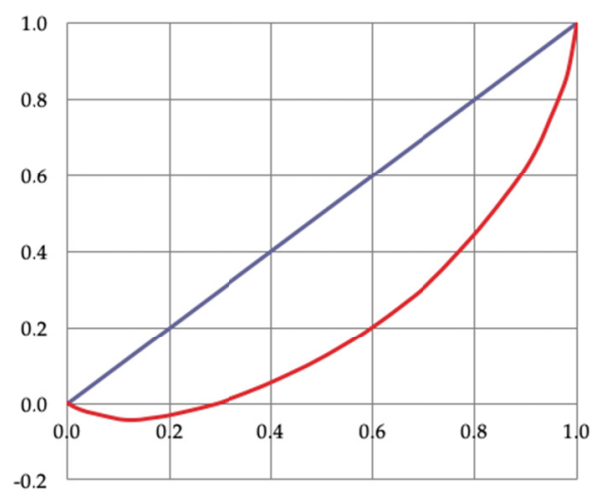

Bao Thang district $(\mathrm{G}=0.5776)$

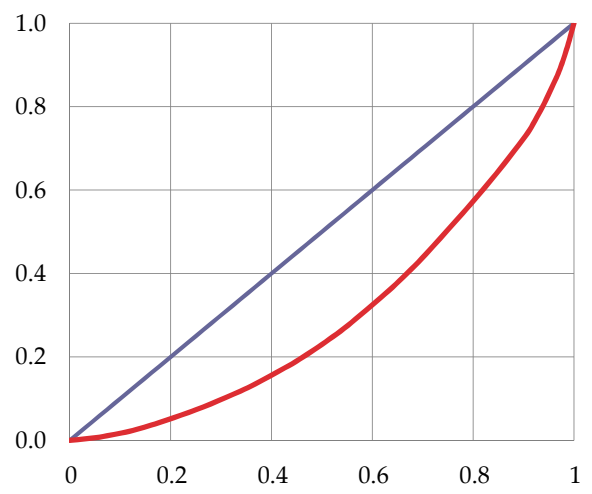

Muong Khuong district $(\mathrm{G}=0.2581)$

Figure 5. Lorenz curve in the research site

The study also attempts to estimate the impact of financial development on the distribution of agricultural output reflected through the relationship between formal credit and inequality in the research site. It is important to note that Bao Thang has the most effective banking sector, meanwhile Muong Khuong has the lowest level. These results are also consistent with the previous study conducted by Anh et al. (2011), the researchers pointed out that the inequality in the pre-urban areas is higher than the rural area and public services serve majorly to the 
better-off households. Look at the graphs in Figure 4, it can be seen that there is a strong differential in terms of inequality of agricultural value addition in the research site. Overall, the Gini coefficient of the whole sample is 0.5242. This is higher than the ratio of the nation's residents and NMM region in 2016 at 0.431 and 0.433 , respectively (GSO, 2016). The Gini indexes at three studied districts also reveal interesting results.

Surprisingly, Bao Thang, the district has the best banking industry, also is the highest level of inequality. This result is contrary to our initial hypothesis that financial development (i.e. increasing access to credit) significantly contributes to reducing the agricultural income gap and inequality. The household survey also reveals that local farmers are facing various credit and non-credit difficulties. More dangerously, many respondents reported that they success in access credit and enlarge their agricultural investment. However, their skill and knowledge have not enhanced properly with larger scale and/or new technical requirement of agricultural products. Consequently, they probably suffer from various difficulties related to markets, risks, climate..., and hence, to cause crop failure and unmarketable products, or both. It is concluded that in order to support the agriculture sector, only credit is not enough, but also it is required to have effective interventions to minimize risks and maximize profit for farmers.

In opposition, Muong Khuong banking sector is considered the lowest development level and the outreach of formal credit has also been obtained the limited result. As aforementioned, this puzzle comes from not only actors like borrowers, lenders, local authorities but also other related factors such as infrastructure, demography, and conception about debtors, especially ethnic minorities. Turn back to district Gini coefficient, here, it takes the value at 0.2581 , the relatively ideal index compared to the global figure (Note 7). It seems that this is the unique bright point found out in the leaden picture as drew by Laquihon (1992) and Ranaweera (1993), "the Asian uplands are characterized by poverty, hunger, hopelessness, discontent, greediness, and exploitation".

Unfortunately, the findings of the household survey show several latent consequences have been taking place under the effect of formal credit service disbursed through the community-based method. Specifically, local authorities play a crucial role in the screening process of banks in providing preferential credit through their assessment about applicants to banks. This process was taken place personally and objectively because of corruption and nepotism, hence, causing the negative impact on not only kith and kin but also non-kind relationships. This finding is consistent with the work of T. Dufhues (2007) and Hoang et al. (2016) conducted in Northern Vietnam. In addition, the poorer households usually use social capital (i.e. social network) as the most important type to overcome financial shock (Fischer et al., 2010) because it is not easy for them to access the saving and insurance service. Now, the vulnerable group felt that it is more difficult to apply this kind of capital and they felt to be isolated in their own community or relationship, or both. According to Kawachi et al. (1997), the researcher hypothesized and proved that income inequality leads to increased mortality via disinvestment in social capital. The author concurs with this statement, and at the same time, warns policy-makers that poverty reduction programs need to be more effective and more accurately targeted to avoid conflicts in society and other unexpected consequences in upland areas, where ethnic minority tribes are living in.

\section{Conclusions}

Besides providing an agricultural credit market, the paper examines two levels of objectives: (1) the micro-impact of credit access on households' agricultural production and other welfares; (2) the community-impact on agricultural income inequality influenced by financial development. At the first contribution, the study points out that small farmers are suffering from the triple unreasonable disadvantages compared to the basic market fundamentals, the smallest loan amount, highest interest rate and the shortest duration. It is considered a kind of inequality of disadvantaged households in access to preferential credit, which is designed for them as the national fiscal burden. Among bank-borrowers, the role of VBARD deserves recognition by their customers, while that of VBSP is extremely fuzzy.

At the grass-root level, this paper finds out the significantly positive impact of formal credit access on total income, on-farm and off-farm, and living expenditure of local people. More specifically, better credit access enables to raise the agricultural investment, especially in small farmers, leading an increase in their output and value added. Compared to credit-constrained households, the non-constraint farmers clearly obtained higher effectiveness in livestock production but the differentiation in cultivating is mere and insignificant. Furthermore, the paper also finds the positive transition of the structure within the agriculture sector. More detailed, it is recognized that better credit access enables farmers to likely develop raising animals, that does not depend strongly on agricultural land. In the context of the scarcity of cultivated land, it plays an essential role in local livelihood and poverty reduction.

At the community-impact level, not as expected, it is highlighted that financial facilitation without 
agriculture-related supports causes to the negative effect on the agricultural outcomes and prolongs the inequality in the locality. In addition, under the community-based lending method, clerks heavily depend on the assessment of local authorities in order to make decisions on how loans approved. It may cause to not only the leakage of preferential credit but also weaken social capital in rural areas, especially in upland areas where almost ethnic minorities living.

With the aim of boosting the agricultural sector and rural development, absolutely, all concerns above must be removed. To do that, various steps and mechanisms needed also have to also change. For policy-makers, breaking the quasi-monopoly of the formal credit market is considered the first priority to create a competitive financial market toward market-oriented and sustainability. For banks, they need to change the mindset about target clients as Government's mandates, either commercial (VBARD) or development (VBSP) purpose, scratching out the drawback of farmer borrowers generated from banks' credit allocation. For farmers, it is necessary to enhance agricultural production and the niche market before trying to get a loan. Otherwise, they have to face with various unpredictable risks, especially their products strongly depend on the Chinese market. Besides develop some kinds of the cluster of agricultural production point, for example, the common interest groups (CIGs), farmers need to facilitate from the central Government through the investment in the productive infrastructure and agricultural service system.

Author Contributions: Phillipe Lebailly is the promoter of this Ph.D. research. He guided instructions for the research approach and revised the paper. Ho Thi Minh Hop contributed to the research design and commented on the revision of the paper. Philippe Burny and Thomas Dogot provided various comments for the research approach of the paper. Tran Huu Cuong is the co-promoter of this Ph.D. research in Vietnam. He contributed to the research design and commented on the revisions of the paper. Bui Thi Lam, a Ph.D. student, collected data through the field trips in Vietnam, developed the paper and provided responses for the journal's reviewers as well as the Editorial Board. All the authors read and approved the final manuscript.

Funding: The authors are grateful to Vietnam International Education Development (VIED) for providing financial assistance to this study.

Conflicts of Interest: The authors declare no conflict of interest.

\section{Acknowledgments}

The authors express deep gratitude to the anonymous referees and the editor of this journal for valuable comments and suggestions on an earlier draft of the article. The authors would like to thank Dr. Nguyen Ngoc Quang, who is working at the International Fund for Agricultural Development (IFAD) as Rural Development and Commodity Chain Analysis Specialist, for his valuable comments about the research topic. The analyses expressed here are the authors' alone.

\section{References}

ADB (Asian Development Bank) (2010). Microfinance Assessment of Asian Development Bank TA-7499-VIE: Developing Microfinance Sector in Vietnam, Manila, Philippines. Retrieved from https://www.adb.org/sites/ default/files/project-document/75628/42235-012-vie-tacr.pdf

Anh, L. H., Giam, D. Q., Lam, B. T., Huyen, V. N., \& Cuong, T. H. (2011). Equitability in access to rural public services in Vietnam: an outlook from the red river delta. International Business and Management (pp. 209 218). http://dx.doi.org/10.3968/j.ibm.1923842820110201.016

Beck, T., Demirgüç-Kunt, A., \& Levine, R. (2007). Finance, Inequality, and Poverty: Cross-Country Evidence. https://doi.org/10.1596/1813-9450-3338

Biernacki, P., \& Waldorf, D. (1981). Snowball sampling: Problems and techniques of chain referral sampling. Sociological methods \& research, 10(2), 141-163. https://doi.org/10.1177/004912418101000205

Bui, T. L., Tran, H. C., Azadi, H., \& Lebailly, P. (2018). Improving the Technical Efficiency of Sengcu Rice Producers through Better Financial Management and Sustainable Farming Practices in Mountainous Areas of Vietnam. Sustainability, 10 (7), 1-19. https://doi.org/10.3390/su10072279

Cuong, N. V. (2008). Is a governmental Micro-Credit Program for the poor really pro-poor? Evidence from Vietnam. The Developing Economies, 46 (2), 151-187. https://doi.org/10.1111/j.1746-1049.2008.00061.x

Diagne, A., Zeller, M., \& Sharma, M. (2000). Empirical measurements of households' access to credit and credit constraints in developing countries: Methodological issues and evidence: Citeseer. Retrieved from https://pdfs.semanticscholar.org/7b67/65562350afc6231a32153dfc552cf99fbc58.pdf 
Do Xuan, L., \& Bauer, S. (2016). Does credit access affect household income homogeneously across different groups of credit recipients? Evidence from rural Vietnam. Journal of rural studies, 47, 186-203. https://doi.org/10.1016/j.jrurstud.2016.08.001

Dufhues, T. (2007). Accessing rural finance: The rural financial market in Northern Vietnam: Studies on the Agricultural and Food Sector in Central and Eastern Europe. Retrieved from https://ageconsearch.umn.edu/record/92327

Dufhues, T., \& Buchenrieder, G. (2005). Outreach of credit institutes and households' access constraints to formal credit in Northern Vietnam. Retrieved from https://ageconsearch.umn.edu/record/8535

Dufhues, T. B., Dung, P. T. M., Hanh, H. T., \& Buchenrieder, G. (2002). Information and targeting policies and their principal-agent relationships-The case of the Vietnam Bank for the Poor. Quarterly J. of International Agriculture, 41(4), 335-362. Retrieved from https://ageconsearch.umn.edu/bitstream/8535/1/dp050001.pdf

Duong, P. B., \& Izumida, Y. (2002). Rural development finance in Vietnam: A microeconometric analysis of household surveys. World development, 30(2), 319-335. https://doi.org/10.1016/S0305-750X(01)00112-7

Duong, P. B., \& Thanh, P. T. (2014). Impact evaluation of microcredit on welfare of the Vietnamese rural households. Asian Social Science, 11(2), 190. http://dx.doi.org/10.5539/ass.v11n2p190

FAO (Food and Agriculture Organization). (2017). Innovative risk management strategies in rural and agriculture finance - The Asian experience (Ed.: Emilio Hernández). Rome, Italy. Retrieved from http://www.fao.org/3/a-i6940e.pdf

FAO. (2018). Agricultural investment funds for development - Descriptive analysis and lessons learned from fund management, performance and private-public collaboration. By Miller C., Ono T., Petruljeskov M., Rome, Italy. Retrieved from http://www.fao.org/3/I8226EN/i8226en.pdf

Fischer, I., Beuchelt, T., Dufhues, T., \& Buchenrieder, G. (2010). Risk management networks of ethnic minorities in Viet Nam. Asia-Pacific Development J., 17(2), 83-118. https://doi.org/10.18356/cb961558-en

Germidis, D. A., Kessler, D., \& Meghir, R. (1991). Financial systems and development: What role for the formal and informal financial sectors? OECD. Retrieved from http://www.gdrc.org/icm/formal-informal.html

Giang, H. (2004). Rural Credit Markets in Vietnam: Theory and Practice. Retrieved from https://www.minneapolisfed.org/ /media/files/mea/contest/2004papers/ho.pdf?la=en

Gini, C. (1912). Concentration and dependency ratios (in Italian). English translation in Rivista di Politica Economica, 87(1997), 769-789.

GSO (General Statistics Office of Vietnam). (2016). The results of the Vietnam Household Living Standard Survey (VHLSS) 2016. General Statistis Office.

GSO (General Statistics Office of Vietnam). (2017). Statistical Yearbook of Vietnam: Social-Economical Data from 1990 to 2017. Retrieved from https://www.gso.gov.vn/default_en.aspx?tabid=515\&idmid=5\&ItemID= 18533

HLPE (High Level Panel of Experts) (2013). Investing in smallholder agriculture for food security. A report by the High Level Panel of Experts on Food Security and Nutrition of the Committee on World Food Security, Rome. Retrieved from http://www.fao.org/3/a-i2953e.pdf

Hoang, Q. D., Dufhues, T. B., \& Buchenrieder, G. (2016). Individual social capital and access to rural services in Northern Vietnam. Inter. J. of Social Eco., 43(4), 363-381. https://doi.org/10.1108/IJSE-12-2012-0234

IFC (International Finance Corporation). (2014). Access to Finance for Smallholder Farmers: Learning from the Experiences of Microfinance Institutions in Latin America. Retrieved from https://www.ifc.org/wps/wcm/ connect/071dd78045eadb5cb067b99916182e35/A2F+for+Smallholder+Farmers-Final+English+Publicatio n.pdf?MOD=AJPERES

Kawachi, I., Kennedy, B. P., Lochner, K., \& Prothrow-Stith, D. (1997). Social capital, income inequality, and mortality. American Journal of Public Health, 87(9), 1491-1498. http://doi:10.2105/AJPH.87.9.1491

Khandker, S. R., \& Koolwal, G. B. (2016). How has microcredit supported agriculture? Evidence using panel data from Bangladesh. Agricultural Economics, 47(2), 157-168. https://doi.org/10.1111/agec.12185

Laquihon, W. A., Watson, H. R. \& Palmer, J. J. (1992). Sloping agriculture land technology (SALT): A decade of experience on hillside sustainability. Paper read at the Asian Farming Systems Symposium - 1992, Colombo, Sri Lanka. 
Le Thi Minh, C., Lebailly, P., \& Nguyen Tuan, S. (2012). Access to credit of animal production households: A study in Hai Duong province, Vietnam. Journal Science and Development, 10(7), 1050-1060. Retrieved from https://orbi.uliege.be/handle/2268/150408

Lensink, R., \& Pham, T. T. T. (2012). The impact of microcredit on self-employment profits in Vietnam. Economics of transition, 20(1), 73-111. https://doi.org/10.1111/j.1468-0351.2011.00427.x

Lorenz, M. O. (1905). Methods of measuring the concentration of wealth. Publications of the American statistical association, 9(70), 209-219.

Madestam, A. (2014). Informal finance: A theory of moneylenders. Journal of Development Economics, 107, 157-174. https://doi.org/10.1016/j.jdeveco.2013.11.001

Molini, V., \& Wan, G. (2008). Discovering sources of inequality in transition economies: a case study of rural Vietnam. Economic Change and Restructuring, 41(1), 75-96. https://doi.org/10.1007/s10644-008-9042-8

MOLISA (Ministry of Labour, Invalids and Social Affairs of Vietnam) (2016). Poverty Report of Vietnam Ministry of Labor - War Invalids and Social Affairs.

Mookerjee, R., \& Kalipioni, P. (2010). Availability of financial services and income inequality: The evidence from many countries. Emerging Markets Review, 11(4), 404-408. https://doi.org/10.1016/j.ememar.2010.07.001

Moore, W., \& Craigwell, R. (2003). The relationship between commercial banks' interest rates and loan sizes: evidence from a small open economy. Applied Financial Economics, 13(4), 257-266. https://doi.org/10.1080/09603100110116434

Murphy, M. M., \& Ott, M. (1977). Retail credit, credit cards and price discrimination. Southern Economic Journal, 1303-1312.

Neuberger, D. (1997). Structure, conduct and performance in banking markets: Thünen-Series of Applied Economic Theory. Retrieved from http://hdl.handle.net/10419/78254

Nguyen, C., Bigman, D., Van den Berg, M., \& Vu, T. (2007). Impact of Micro-credit on Poverty and Inequality: The Case of the Vietnam Bank for Social Policies. Retrieved from https://mpra.ub.uni-muenchen.de/54154/

OI (Opportunity International) (2013). Financing smallholder farmers to increase incomes and transform lives in rural communities. Retrieved from http://www.fao.org/family-farming/detail/en/c/298477/

Pham, T. T., Katsuhiro, S., \& Pham, B. D. (2019). Impact of microcredit on rural household welfare and economic growth in Vietnam. Journal of Policy Modeling, 41(1), 120-139. https://doi.org/10.1016/j.jpolmod.2019.02.007

Phan, D. K., Gan, C., Nartea, G. V., \& Cohen, D. A. (2014). The impact of microcredit on rural households in the Mekong River Delta of Vietnam. Journal of the Asia Pacific Economy, 19(4), 558-578. https://doi.org/10.1080/13547860.2014.920591

Quach, M., Mullineux, A., \& Murinde, V. (2005). Access to credit and household poverty reduction in rural Vietnam: A cross-sectional study. The Birmingham Business School, The University of Birmingham Edgbaston, 1-40. Retrieved from http://www.grips.ac.jp/vietnam/VDFTokyo/Doc/1stConf18Jun05/OPP 01QuachPPR.pdf

Ranaweera, N. (1993). Upland Agriculture in Asia: How Sustainable is it. Paper presented at the Upland Agriculture in Asia. Proceedings of a Workshop Held in Bogor, Indonesia April. Page 143 - 152. Retrieved from https://pingpdf.com/pdf-upland-agriculture-in-asia-capsa.html

Saito, K. A., \& Villanueva, D. P. (1981). Transaction costs of credit to the small-scale sector in the Philippines. Economic Development and Cultural Change, 29(3), 631-640. https://doi.org/10.1086/451275

Sauli, H., Quang, N., \& Emilio, H. (2017). Innovations and inclusive investments for agricultural development in Viet Nam. In E. Hernández (Ed.), Chapter 3 in the book Innovative risk management strategies in rural and agriculture finance: The Asian experience. Rome, Italy. Retrieved from http://www.fao.org/3/a-i6940e.pdf

Sergio, N., Mark, S., Richard, L. M., Claudio, G.-v., \& Jorge, R.-m. (2000). Microcredit and the Poorest of the Poor: Theory and Evidence From Bolivia. https://doi.org/10.1016/S0305-750X(99)00121-7

Springer-Heinze, A. (2018). ValueLinks 2.0. Manual on Sustainable Value Chain Development, GIZ Eschborn, 2 volumes (Vol. 1). Retrieved from http://valuelinks.org/wp-content/uploads/2015/09/ValueLinks-Manual-2.0Vol-1-January-2018.pdf 
Stewart, R., Van Rooyen, C., Korth, M., Chereni, A., Da Silva, N. R., \& De Wet, T. (2012). Do Micro-credit, Micro-savings and Micro-leasing Serve as Effective Financial Inclusion Interventions Enabling Poor People, and Especially Women, to Engage in Meaningful Economic Opportunities in Low-and Middle-income Countries?: A Systematic Review of the Evidence: EPPI-Centre. Retrieved from https://eppi.ioe.ac.uk/cms/LinkClick.aspx?fileticket=pl1Whdj1_5s\%3D\&tabid=3352\&mid=6527

Thanh Tam, L. (2011). Vietnam rural financial market-Fact dianostics and the policy implications for rural development of Vietnam. Journal of Economics and Development, 13(1), 57. Retrieved from http://jed.neu.edu.vn/Uploads/JED\%20Issue/Article\%204_JED\%20Vol\%2013_\%20No.1_\%202011.pdf

Tuan, N. D. A. (2010). Vietnam's Agrarian Reform, Rural Livelihood and Policy Issues. Retrieved from https://www.rimisp.org/wp-content/uploads/2010/05/Paper_Nguyen_Do_Anh_Tuan.pdf

Varghese, A. (2004). Bank-moneylender credit linkages: theory and practice: Mimeo Texas AM University. Retrieved from https://pdfs.semanticscholar.org/34d8/20e153b87c87d1787d1904499ac021551a08.pdf

Varian, H. (1989). Price discrimination, in the Handbook of Industrial Organization: North Holland, Amsterdam.

VBSP. (2018). Annual report of Vietnam Bank for Social Policy in 2017. Retrieved from http://vbsp.org.vn/ wp-content/uploads/2019/05/BAO-CAO-THUONG-NIEN-2017_-NHCSXH_-bong-9.pdf

WorldBank. (2008). Agriculture for Development - World Bank Group. Retrieved from https://siteresources.worldbank.org/INTWDR2008/Resources/WDR_00_book.pdf

World Bank. (2014). Vietnam - Financial sector assessment. Financial Sector Assessment Program (FSAP). Washington, DC: World Bank Group. Retrieved from http://documents.worldbank.org/curated/en/21 6401468329363389/Vietnam-Financial-sector-assessment

Zeller, M. (1994). Determinants of credit rationing: A study of informal lenders and formal credit groups in Madagascar. World development, 22(12), 1895-1907. https://doi.org/10.1016/0305-750X(94)90181-3

Zeller, M., Ahmed, A. U., Babu, S. C., Broca, S., Diagne, A., \& Sharma, M. P. (1996). Rural Finance Policies for Food Security of the Poor: Methodologies for a Multicountry Research Project. Retrieved from https://ageconsearch.umn.edu/record/97308/

\section{Notes}

Note 1. See at http://mis.chuongtrinh135.vn/default.aspx?T=4\&db=31

Note 2. https://thuvienphapluat.vn/van-ban/EN/Van-hoa-Xa-hoi/Resolution-No-30a-2008-NQ-CP-of-December27-2008-on-the-support-program-for-fast-and-sustainable-poverty-reduction-in-61-poor-districts/86655/tieng-an h. $\operatorname{aspx}$ ?tab=7

Note 3. http://documents.worldbank.org/curated/en/600321468311661141/Vietnam-Second-Northern-Mountains -Poverty-Reduction-Project

Note 4. This rate is much lower than other studies carried out a decade ago, like Dao (2002) and McCarty (2001), the researchers stated the fee around $3-10 \%$ per month.

Note 5. The lump-sum payment is often regulated that the principal is paid in one single payment in lieu of broken up into installments.

Note 6 . This is the concept describing the ways in which people try to optimize their lifetime standard of living by ensuring a proper balance of spending and saving during the different phases of their life.

Note 7. https://data.worldbank.org/indicator/si.pov.gini? end=1980\&most_recent_value_desc $=$ false\&start=1980 \&view=bar

\section{Copyrights}

Copyright for this article is retained by the author(s), with first publication rights granted to the journal.

This is an open-access article distributed under the terms and conditions of the Creative Commons Attribution license (http://creativecommons.org/licenses/by/4.0/). 